${ }^{1}$ Medical Faculty. Foča. University of East Sarajevo. Bosnia and Herzegovina. ${ }^{2}$ General Hospital. Valjevo. Serbia. ${ }^{3}$ Faculty of special education and rehabilitation. University of Belgrade. Serbia.

Recibido el 16 de octubre de 2013, aceptado el 10 de marzo de 2014.

Corresponding author:

Sinisa Ristic, M.D., Ph.D. Address: Studentska 1, 73300 Foča, Bosnia and Herzegovina Telephone numbers: 0038765960797 risticsinisa@yahoo.com

\section{The role of the psychiatrist in obtaining informed consent from patients with somatic and mental comorbidity. Report of one case}

\author{
SNEZANA MEDENICA ${ }^{1}$, MAJA RACIC ${ }^{1}$, MIRA VUKOVIC ${ }^{2}$, \\ SINISA RISTIC ${ }^{1}$, JASMINA KARIC ${ }^{1,3}$
}

\begin{abstract}
The nature of mental disorders, the attitudes and prejudices of the social community towards psychiatric patients, the behavior and treatment of mental patients, all bring about numerous dilemmas and prejudices. When a patient is diagnosed with a mental disorder, he may suffer restrictions in the field of general human rights. However, the biggest problems in clinical practice occur in the treatment of patients who, besides their mental disorder also have a somatic disease. We report a 56-years-old female with a severe renal failure who refused to undergo dialysis. Following the patient's refusal to sign an informed consent, a psychiatrist was called in for consultation and diagnosed an acute psychotic reaction. To manage the delusions and acute psychotic reactions, risperidone in the dose of $2 \mathrm{mg}$ was started. After 22 days, the patient still had marked psychotic symptoms. A psychiatrist, a nephrologist and an anesthesiologist, in the presence of the spouse on the grounds of her life-threatening condition, decided to apply the necessary medical procedures even without the patient's consent. A day after the start of dialysis the patient still had delusional ideas, but without the presence of anxiety, and the patient no longer offered resistance to dialysis. Four days after the first dialysis, the patient was calm, had vague memories about the entire previous period, and signed the informed consent concerning her further treatment.
\end{abstract}

(Rev Med Chile 2014; 142: 512-515)

Key words: Dialysis; Informed consent; Psychiatry; Psychotic disorders.

\section{Obtención de consentimiento informado por un psiquiatra en un paciente con una enfermedad somática. Informe de un caso}

Se generan muchos dilemas y prejuicios debido a la naturaleza de las enfermedades mentales. Cuando a un paciente se le diagnostica un cuadro mental, sus derechos humanos pueden verse perjudicados. Sin embargo, los mayores problemas se suscitan en pacientes que además de tener un trastorno mental, tienen una enfermedad somática. Presentamos una mujer de 56 años con una falla renal que rechazó ser dializada. Después que la paciente no firmó el consentimiento informado, se pidió una interconsulta a psiquiatría y se diagnosticó una reacción psicótica aguda. Se indicó risperidona para tratar las alucinaciones. 
Después de 22 días de tratamiento la paciente aún tenía síntomas psicóticos. Una junta médica efectuada en la presencia del cónyuge de la paciente, decidió efectuar la diálisis a pesar del rechazo de la paciente. Un día después de dializarse, la paciente aún tenía alucinaciones pero menos ansiedad y dejó de rechazar la diálisis. Cuatro días más tarde la paciente no recordaba lo ocurrido y firmó el consentimiento para dializarse.

4 plis thics and legal regulations are rather complex in psychiatry. The nature of mental disorders, the attitudes and prejudices of social community towards psychiatric patients, the behavior and treatment of mental patients, all bring about numerous dilemmas and challenges. However, the biggest problems in clinical practice occur in the treatment of patients who beside their mental disorder also have a somatic disease $\mathrm{e}^{1-4}$. Numerous psychological reactions have been noticed in patients during hospital treatment. Their stay in the hospital, as well as the treatment itself, numerous diagnostic examinations or medical interventions are all extremely stressful for the majority of patients. The hardest problem occurs when, due to noticeable somatic difficulties, patients need a complex medical intervention, but due to their current mental state they are not capable of grasping the information they have been given. One of the basic rights of the patient is the right to be informed and to make decisions about his/her own health. In principle, the patient is entitled to all information pertaining to his/her disease, condition, prognosis, treatment options, adverse effects, side effects and risks of treatment, as well as chances of success ${ }^{5}$.

\section{Case study}

A 56-year-old female patient was admitted to Cardiology for dyspnea, chest discomfort, fatigue and vomiting over the past three days. During the examination and extended clinical and laboratory evaluation the patient was found to have kidney failure. On admission to Nephrology, the patient was told that she had a severe renal function disorder and that it was necessary to put her on dialysis. The patient was also given the necessary information about the dialysis procedure as well as the risks if it is not received. However, the patient refused to have a central venous catheter installed, which was necessary for her to receive dialysis. Fo- llowing the patient's refusal to sign informed consent, a psychiatrist was called in for consultations. After an examination, the psychiatrist diagnosed the patient with acute psychotic reaction. The psychiatrist stated that the patient had delusional ideas (the patient suspects that she was being poisoned). The psychiatrist also determined that the patient was cognitively slowed, with anxiety, and that she did not grasp her medical condition. Risperidone was introduced as a therapy.

Five days after starting psychiatric therapy the patient still refused to have a central venous catheter installed, so the psychiatrist suggests that the local Social Welfare Center should be informed about the situation so that a temporary guardian could be responsible for the patient. Over the following two days, the Social Welfare Center appointed her husband as the temporary guardian.

On the 14th day after admission, the patient complained of shortness of breath. Overall, the heart was moderately augmented with a myopathic tendency.

After 22 days upon reception, the patient still had a marked psychotic symptomatology. A consilium of doctors, comprising a psychiatrist, a nephrologist and an anesthesiologist, in the presence of the spouse, on the grounds of her life-threatening condition, decided to apply the necessary medical procedures without the patient's consent. Also prepared was a protocol of planned medical interventions and therapy for the patient. The spouse, as the temporary guardian, gave written consent to install the central venous catheter and apply dialysis. The patient was still on risperidone therapy.

A day after dialysis the patient still had delusional ideas, but without the presence of anxiety, and the patient no longer offered resistance to dialysis. Four days after the first dialysis, the patient was calm, had vague memories about the entire previous period, and eventually signed informed consent concerning her further treatment. 


\section{Discussion}

There have been a growing number of psychological disorders reported in various categories of organic patients. Also there are numerous mental disorders reported that may occur while patients are treated for some organic disease.

Liaison psychiatry has studied various models of patient behavior in the state of active disease, then also patient reactions to their own disease, especially the patients' attitude towards own disease, knowledge of specific mental characteristic of certain somatic patients ${ }^{6}$. Its importance and significance lie exactly in the right assessment of the patient's mental state and timely inclusion of a psychiatrist.

In our clinical practice, the most frequent reason for including a psychiatrist in the treatment of patients on non-psychiatric wards is in those situations where patients disclose that they have already been treated by a psychiatrist or when they refuse to give consent to medical intervention, after a suicide attempt, as well as in the case of a serious change in behavior.

A patient's ability to give consent is established by a medical doctor or a psychiatrist at the time when the person makes such a decision, and for that purpose issues a written certificate, which is then attached to the medical records. The psychiatrist must assess whether the patient is capable of comprehending the information provided, and whether he/she can competently decide on his/her treatment ${ }^{7}$. Subject to assessment is the patient's current mental state (time and space orientation, and orientation towards other people, whether contact with the patient has been established, whether he/she is ready to cooperate, the ability to critically assess his/her condition and the necessity of the proposed treatment). In our case, in accordance with the Republic of Serbia Law on Health Protection ${ }^{8}$, we informed the patient about all relevant data pertaining to the nature of her problems, the options and methods of treatment, possible adverse effects of the therapy, other methods of treatment, consequences of failure to receive dialysis, dialysis procedure, as well as the need to install a central venous catheter. All the information has been presented to the patient repeatedly. Despite all the information provided, as well as the introduced psychiatric therapy, the psychiatrist's assessment was that the patient did not comprehend the serious condition she was in, or the necessity of the proposed medical procedures and interventions. The Social Welfare Center was called upon, and based on all available information they decided to appoint a temporary guardian.

In psychiatric theory and practice, this problem has a special significance in relation to other fields of medicine, since many mental disorders may temporarily or even permanently reduce patient's mental capacities to the point where they are not able to give valid consent to undertake a certain diagnostic, therapeutic or some other medical procedure $^{9,10}$. The Hawaii Declaration (HD) issued by the World Psychiatric Association points out that no procedure should be carried out, nor should any treatment be applied against or independently of the patient's personal will, save in cases where the patient, due to a mental illness, is not capable of telling what is in his best interest, and if without the treatment the patient and others could suffer serious detrimental consequences ${ }^{11}$. The HD provides a possibility that with the help of his relatives the patient might be persuaded to give consent to treatment. In our example, we made an assessment as to what is best for the patient. Subject of assessment were her mental capacity and her current health condition. We gave the patient enough time to make the decision autonomously, mindful of the course of disease and risks of waiting for the necessary intervention. In the meantime, the Social Welfare Center was informed about the situation, which made it possible for the medical decision of the team of physicians to be implemented in a legal and ethical manner ${ }^{12-16}$. In this case, the interdisciplinary approach and team work were of decisive importance. After taking an exhaustive history and making a relevant risk assessment, the team decided to have the patient's spouse included in the decision-making process regarding further treatment and implementation of necessary medical measures. It is important to note that, just as we did not pressure the patient herself during her hospitalization, we also did not exert any pressure whatsoever on her temporary guardian. Our task was to inform him in detail about the necessity to carry out a medical intervention and all the risks it entails for his spouse, as well as about possible consequences if it is not done.

The patient's mental condition was monitored throughout. The entire team of health profes- 
sionals who participated in treating the patient carefully followed the course and changes in her psychological perception, but also the patient's reactions to the introduced psychiatric therapy. The psychiatrist basically trained the entire medical staff in how to recognize and follow the patient's psychological experiences and her reactions to the disease, which is in accordance with the Madrid Declaration obligating the psychiatrist to permanently upgrade his knowledge and convey it to others ${ }^{17}$.

In this way we have managed to preserve respect for the dignity of the patients with all her rights, her autonomy, to protect her in a situation where she was not able to make an important decision, to see her through the entire period during which she managed to regain composure, and restore her independence in decision-making.

\section{References}

1. Iacovides A, Siamouli M. Comorbid mental and somatic disorders: an epidemiological perspective. Curr Opin Psychiatry 2008; 21 (4): 417-21.

2. Fava GA, Sonino N. Psychosomatic medicine: emerging trends and perspectives. Psychother Psychosom 2000; 69: 184-97.

3. Hodes M, Moorey S. Psychological treatment in disease and illness. London. Gaskel and the Society for Psychosomatic Research, 1993.

4. Vuković M, Gvozdenović BS, Stamatović-Gajić B, Ilić M, Gajić T. Development and evaluation of the nurse quality of communication with patient questionnaire. Srp Arh Celok Lek 2010; 138 (1-2): 79-84.

5. Kaličanin P. Medicinska etika i medicinsko pravo. Beograd: Institut za mentalno zdravlje; 1999.
6. Liaison psychiatry and the management of long-term conditions and medically unexplained symptoms. Royal College of Psychiatrists' Faculty of Liaison Psychiatry. London, 2012 http://www.rcpsych.ac.uk/pdf/Liaisonpsychiatry-faculty-report.pdf. (Accepted july 2013).

7. Stojić D, Goreta M. Značenje. "Informiranog pristanka" prema Zakonu o zaštiti osoba s duševnim smetnjama. In: Goreta M., Jukić V., Turković K, ed. Psihijatrija i zakon. Zagreb: Psihijatrijska bolnica Vrapče; 1998.p. 09115.

8. Zakon o zdravstvenoj zaštiti, Službeni glasnik RS, Br. 107/05,

9. Goreta M, Jukić V, Turković K. Psihijatrija i zakon. Zagreb: Psihijatrijska bolnica Vrapče; 1998.

10. Medenica S, Timotijević I, Pantić Z. Measures of involuntary hospitalization of mental patients-experiences of the psychiatric department in Health center Valjevo. Psych Today 2004; 36 (1): 69-78.

11. World Psychiatric Association. Declaration of Hawaii. WPA General Assembly; 1977; Hawaii. http://www. codex.vr.se/texts/hawaii.html (Accepted july 2013).

12. Porodični zakon. Službeni glasnik RS, br. 22/80, 11/88, 22/93, 35/94

13. Zakon o socijalnoj zaštiti i obezbeđivanju socijalne sigurnosti građana, Službeni glasnik RS, Br. 36/91, 79/91, 33/93, 53/93, 67/93, 46/94, 48/94, 52/96, 29/01, 84/04.

14. Mental Disability Advocacy Center Starateljstvo i ljudska prava u Srbiji. Analiza pravnog uređenja i prakse starateljstva u Srbiji, 2006.

15. Ljubojev N. Starateljstvo nad punoletnim licima u Jugoslovenskom pravu. Beograd: MDAC; 1999. p. 28.

16. CM Documents. 10 Legal Questions. Department of Health Council of Europe White Paper on Mental Health and Human Rights; 2000.

17. Helmchen H, Okasha A. From the Hawaii Declaration to the Declaration of Madrid. Acta Psychiatr Scand 2000; 101: 20-3. 